\title{
Elephant grass genotypes for bioenergy production by direct biomass combustion
}

\author{
Rafael Fiusa de Morais( ${ }^{(1)}$, Bruno Juscelino de Souza(1), José Marcos Leite(1), Luis Henrique de Barros Soares ${ }^{(2)}$, \\ Bruno José Rodrigues Alves ${ }^{(2)}$, Robert Michael Boddey ${ }^{(2)}$ and Segundo Urquiaga ${ }^{(2)}$
}

\begin{abstract}
(1)Universidade Federal Rural do Rio de Janeiro, Departamento de Agronomia e Ciência do Solo, BR 465, Km 7, CEP 23890-000 Seropédica, RJ, Brazil. E-mail: rafaelfiusademorais@gmail.com, juscelinodesouza@yahoo.com.br, josemarcosleite@yahoo.com.br (2)Embrapa Agrobiologia, BR 465, Km 7, CEP 23890-000 Seropédica, RJ, Brazil. E-mail: luis.henrique@cnpab.embrapa.br, bruno@cnpab.embrapa.br, bob@cnpab.embrapa.br, urquiaga@cnpab.embrapa.br
\end{abstract}

\begin{abstract}
The objective of this work was to evaluate elephant grass (Pennisetum purpureum Schum.) genotypes for bioenergy production by direct biomass combustion. Five elephant grass genotypes grown in two different soil types, both of low fertility, were evaluated. The experiment was carried out at Embrapa Agrobiologia field station in Seropédica, RJ, Brazil. The design was in randomized complete blocks, with split plots and four replicates. The genotypes studied were Cameroon, Bag 02, Gramafante, Roxo and CNPGL F06-3. Evaluations were made for biomass production, total biomass nitrogen, biomass nitrogen from biological fixation, carbon/ nitrogen and stem/leaf ratios, and contents of fiber, lignin, cellulose and ash. The dry matter yields ranged from 45 to $67 \mathrm{Mg} \mathrm{ha}^{-1}$. Genotype Roxo had the lowest yield and genotypes Bag 02 and Cameroon had the highest ones. The biomass nitrogen accumulation varied from 240 to $343 \mathrm{~kg} \mathrm{ha}^{-1}$. The plant nitrogen from biological fixation was $51 \%$ in average. The carbon/nitrogen and stem/leaf ratios and the contents of fiber, lignin, cellulose and ash did not vary among the genotypes. The five genotypes are suitable for energy production through combustion.
\end{abstract}

Index terms: Pennisetum purpureum, ash, agroenergy, biological nitrogen fixation, genotype, lignin.

\section{Genótipos de capim-elefante para produção de bioenergia por combustão direta da biomassa}

\begin{abstract}
Resumo - O objetivo deste trabalho foi avaliar genótipos de capim-elefante (Pennisetum purpureum Schum.) quanto ao potencial para a produção de bioenergia por combustão direta da biomassa. Avaliaram-se cinco genótipos de capim-elefante, em dois solos com baixa fertilidade. Os experimentos foram conduzidos na estação experimental da Embrapa Agrobiologia, em Seropédica, RJ. O delineamento experimental foi o de blocos ao acaso, em parcelas subdivididas, com quatro repetições. Os genótipos estudados foram Cameroon, Bag 02, Gramafante, Roxo e CNPGL F06-3. Determinaram-se a produção de biomassa, o acúmulo de nitrogênio na biomassa, o nitrogênio da biomassa proveniente da fixação biológica, as relações carbono/nitrogênio e talo/ folha, e os teores de fibra, lignina, celulose e cinzas da biomassa. A produção de matéria seca variou de 45 a $67 \mathrm{Mg} \mathrm{ha}^{-1}$. A menor produção foi do genótipo Roxo, e as maiores, dos genótipos Bag 02 e Cameroon. O nitrogênio total acumulado na matéria seca variou de 240 a $343 \mathrm{~kg} \mathrm{ha}^{-1}$. Em média, $51 \%$ do nitrogênio foram provenientes da fixação biológica. As relações carbono/nitrogênio e talo/folha e os conteúdos de fibra, lignina, celulose e cinzas não variaram entre os genótipos. Os cinco genótipos constituem materiais adequados para produção de energia pela queima.
\end{abstract}

Termos para indexação: Pennisetum purpureum, cinzas, agroenergia, fixação biológica do nitrogênio, genótipo, lignina.

\section{Introduction}

In recent decades, the search for alternatives to the use of fossil fuels is increasing globally. High international prices of oil and its derivates and concerns about the environment motivate this process. Moreover, there is great expectation on the possible economic benefits from the clean development mechanism projects coming from the use of renewable sources in the agricultural sector, such as bioethanol from sugarcane (Boddey et al., 2008) and eucalyptus timber for coal substitution (Kraxner et al., 2003). There is also a possibility of obtaining energy from plant biomass that could be transformed to charcoal 
or even directly burned for heat production (Samson et al., 2005).

Elephant grass (Pennisetum purpureum Schum.) is highly efficient in fixing atmospheric $\mathrm{CO}_{2}$, being capable of accumulating more than $60 \mathrm{Mg} \mathrm{ha}^{-1}$ of dry matter per year, when under optimal conditions for growth, at high fertilization rates, especially with $\mathrm{N}$, and good water availability (Andrade et al., 2005). Botrel et al. (2000) tested several clones of elephant grass, among which Cameroon, CNPGL 91 F27-01 and CNPGL 91 F06-3. These authors found an annual average productivity of 31,43 and $37 \mathrm{Mg} \mathrm{ha}^{-1}$ of dry matter per year, respectively. Traditionally, this crop has been managed for forage production for dairy cattle due to its high yield and protein content. However, for bioenergy purposes, apart from high dry matter production, the plant material should suit quality parameters for reaching the optimal energetic efficiency, which means high levels of fibre and lignin, and low levels of water, $\mathrm{N}$ and ash (Lemus et al., 2002; McKendry, 2002).

For elephant grass growing in poor $\mathrm{N}$ soils, the average of dry matter production after two cuts per year were about $30 \mathrm{Mg} \mathrm{ha}^{-1}$, and fibre and lignin contents matched the desirable parameters for energy production from direct burning (Quesada, 2005). Protein content was remarkably reduced in comparison to common levels observed in elephant grass genotypes, destined for forage production. Biomass yield levels were not drastically reduced, in comparison to the ones in fertilised systems (Quesada, 2005). The suitability of the biomass for energy production, along with the possibility of two cuts a year, increases the potential of using this crop for energy production purposes (Samson et al., 2005).

The occurrence of diazotrophic bacteria associated with elephant grass, as reported in previous studies (Baldani et al., 1998; Kirchhof et al., 2001), indicates that biological nitrogen fixation (BNF) might play an important role in $\mathrm{N}$ supply to this crop in poor soils.

The objective of this study was to evaluate the production and quality of biomass and the biological nitrogen fixation in elephant grass genotypes, for energy production by direct combustion.

\section{Materials and Methods}

This study was performed in the experimental area of Embrapa Agrobiologia, in Seropédica, RJ, Brazil $\left(22^{\circ} 49^{\prime} 22^{\prime \prime} \mathrm{S}, 43^{\circ} 38^{\prime} 42^{\prime \prime} \mathrm{W}\right.$, at an altitude of $\left.43 \mathrm{~m}\right)$. The experiment was composed of two factors in a split plot array. The main plot was the soil type and the subplot consisted of elephant grass genotypes, in randomized complete block design, with four replicates. The soils under evaluation were Argissolo Vermelho-Amarelo (Typic Hapludult - Acrisol) and a Planosolo Háplico (Typic Albaqult - Planosolo) (Santos et al., 2006), both of low fertility and low plant $\mathrm{N}$ availability (Table 1). The following genotypes of elephant grass were evaluated: Cameroon, Bag 02, Gramafante, Roxo and CNPGL F06-3, all of them from the collection of Embrapa Gado de Leite. Plots were composed of 6 lines with 7-m length, with each row $1 \mathrm{~m}$ spaced apart, giving a total plot area of $42 \mathrm{~m}^{2}$.

At planting, $\mathrm{P}$ and $\mathrm{K}$ fertilizer were applied in the furrows at a rate of $150 \mathrm{~kg} \mathrm{ha}^{-1}$ of $\mathrm{K}_{2} \mathrm{O}(\mathrm{KCl})$ and $100 \mathrm{~kg} \mathrm{ha}^{-1}$ of $\mathrm{P}_{2} \mathrm{O}_{5}$ (single superphosphate), and $60 \mathrm{~kg} \mathrm{ha}^{-1}$ of FTE BR-12. The doses of P, K and micronutrients were applied based on a mean accumulation of these nutrients in elephant grass plants (Andrade et al., 2005; Moreira et al., 2006). No lime application was required (Table 1). Hence, in theory, $\mathrm{N}$ was the only factor limiting plant development in the experiment.

The experiment was set up in October 2005. The first cut was made in June 2006, the second in January 2007 and the third in July 2007. Manual weeding was performed as needed.

At harvesting, plant biomass of a $20 \mathrm{~m}^{-2}$ central area of each plot was cut at ground level and weighed fresh, without separating stem and leaves. Samples were taken to oven dry at $65^{\circ} \mathrm{C}$, until constant weight, for the determination of accumulated dry matter. The proportion of stems and leaves, in each harvested plot, was calculated from ten plants taken at random within each plot, at the time of the cuts. Oven-dried plant samples were ground to $2 \mathrm{~mm}$ in a Wiley mill and, then, powdered in a roller mill similar to that of Smith \& Myung (1990). The N content and the ${ }^{15} \mathrm{~N}$ natural abundance of each sample were analysed

Table 1. Soil chemical fertility parameters of the two soils.

\begin{tabular}{lccccccc}
\hline Soil type & $\begin{array}{c}\mathrm{pH} \\
\left(\mathrm{H}_{2} \mathrm{O}\right)\end{array}$ & \multicolumn{2}{c}{$\begin{array}{c}\mathrm{Al}^{3+} \\
--\left(\mathrm{cmol}_{\mathrm{c}} \mathrm{Cm}^{-3}\right)--\end{array}$} & $\begin{array}{c}\mathrm{Cg}^{2+} \\
-\left(\mathrm{mg} \mathrm{kg}^{-1}\right)-\end{array}$ & $\begin{array}{c}\mathrm{K}^{(1)} \\
\left(\mathrm{g} \mathrm{kg}^{-1}\right)\end{array}$ \\
\hline Acrisol & 6.0 & 0 & 3.0 & 1.55 & 5.2 & 33.7 & 0.95 \\
Planosol & 6.3 & 0 & 2.0 & 0.98 & 9.0 & 24.2 & 0.58 \\
\hline
\end{tabular}

(1)Semi-micro-Kjeldahl method. 
according to Boddey et al. (2001). Total dry matter and $\mathrm{N}$ accumulated by the plants and the proportional BNF contribution were calculated. For the latter, the value of ${ }^{15} \mathrm{~N}$ natural abundance of the whole plant (stems plus leaves) was considered (Yoneyama et al., 1997). Non- $\mathrm{N}_{2}$-fixing weeds were collected from the plots to serve as control plants for the BNF estimation based on the ${ }^{15} \mathrm{~N}$ natural abundance technique (Unkovich et al., 2008). For the first and second biomass cuts the control species considered were Emilia sonchifolia, Tradescantia fluminensis, and Arnica montana, and for the third, Tradescantia fluminensis, Richardia brasiliensis, and Arnica montana. For these species, a composite sample per block for each species was taken, with single plant samples being collected randomly within the plots, along the lines of elephant grass.

The quality analysis of the elephant grass biomass consisted of the determination of fibre content (acid detergent fibre, ADF), cellulose, lignin and ash contents, following the procedure of Van Soest \& Wine (1968). The C:N ratio was calculated considering $45 \% \mathrm{C}$ in plant biomass. The stem/leaf ratio was also calculated considering the dry mass of each part.

The statistical procedures were those of the SAEG 9.1 (Universidade Federal de Viçosa, 2007). Normality and homogeneity of variance of errors were analysed using the Lilliefors and Cochran \& Bartley tests, respectively. The required conditions were met in all cases. The analysis of variance was, then, performed with the application of the F test. Differences between means were separated by the use of Tukey's test at 5\% probability.

\section{Results and Discussion}

A significant interaction between genotype and soil type was observed regarding total dry matter accumulation after the three cuts (Table 2). At the first cut, after 9 months from planting, dry matter accumulation by genotypes Roxo and Cameroon, when grown on the Acrisol, were 20.3 and $29.5 \mathrm{Mg} \mathrm{ha}^{-1}$, respectively, and between 21.1 and $32.0 \mathrm{Mg} \mathrm{ha}^{-1}$, when grown on Planosol. At the second cut, after further 7 months, the greatest dry matter accumulation were observed on the Acrisol, with a significant difference between genotypes Bag 02 and Gramafante, with a production of $18.1 \mathrm{Mg} \mathrm{ha}^{-1}$ and $27.9 \mathrm{Mg} \mathrm{ha}^{-1}$, respectively. For the genotypes grown on the Planosol, there was a significant difference between Roxo and CNPGL F 06-3, with total dry matter production of 18.8 and $22.8 \mathrm{Mg} \mathrm{ha}^{-1}$, respectively. At the last cut, after the further 6 months of growth, the dry matter accumulation ranged from 6.7 to $14.5 \mathrm{Mg} \mathrm{ha}^{-1}$ on the Acrisol, with the lowest value observed for genotype Roxo and the largest for genotype Bag 02. On the Planosol, dry matter varied from 5.1 to $10.9 \mathrm{Mg} \mathrm{ha}^{-1}$ for the genotypes Cameroon and Roxo, respectively. The high productive potential for biomass production observed with elephant grass in the present study is consistent with those already reported in literature (Queiroz Filho et al., 2000; Magalhães et al., 2006). Still, the positive results hereby shown are of great relevance for the agroenergy sector, as no $\mathrm{N}$ fertilizer was applied and the soils studied were $\mathrm{N}$ depleted.

The high performance in dry matter accumulation was consequently accompanied by a high $\mathrm{N}$ accumulation by plants (Table 3). However, at the first cut, there were no statistical differences among genotypes, regarding $\mathrm{N}$ accumulation, when growing on the Acrisol, with values reaching over $100 \mathrm{~kg} \mathrm{ha}^{-1}$ $\mathrm{N}$. Nevertheless, when growing on the Planosol, differences between the genotypes Gramafante and Cameroon were observed, with values of 92 and $162 \mathrm{~kg} \mathrm{ha}^{-1}$ of accumulated N, respectively. For the second cut, the genotypes Roxo and Gramafante showed the lowest $\mathrm{N}$ accumulation for the two soils, significantly lower than the other genotypes. At the

Table 2. Dry-matter production of elephant grass genotypes, grown in two soils and subjected to three cuts, over a 22-month period ${ }^{(1)}$.

\begin{tabular}{llccl}
\hline Genotype & $1^{\text {st }}$ cut & $2^{\text {nd }}$ cut & $3^{\text {rd }}$ cut & Total \\
\hline & $-------------\left(M g \mathrm{Ma}^{-1}\right)--------------$ \\
CNPGL F06-3 & $26.6 \mathrm{ab}$ & $22.1 \mathrm{ab}$ & $10.7 \mathrm{a}$ & $59.4 \mathrm{~b}$ \\
Gramafante & $23.6 \mathrm{ab}$ & $8.1 \mathrm{~b}$ & $11.7 \mathrm{a}$ & $53.4 \mathrm{bc}$ \\
Bag 02 & $24.3 \mathrm{ab}$ & $27.9 \mathrm{a}$ & $14.5 \mathrm{a}$ & $66.6 \mathrm{a}$ \\
Roxo & $20.3 \mathrm{~b}$ & $26.1 \mathrm{ab}$ & $6.7 \mathrm{~b}$ & $53.0 \mathrm{bc}$ \\
Cameroon & $29.5 \mathrm{a}$ & $20.1 \mathrm{ab}$ & $12.3 \mathrm{a}$ & $61.9 \mathrm{ab}$ \\
\hline Means & 24.9 & 22.9 & 11.2 & 58.9 \\
\hline \multirow{5}{c}{ Planosol } \\
CNPGL F06-3 & $28.4 \mathrm{ab}$ & $22.8 \mathrm{a}$ & $7.0 \mathrm{ab}$ & $58.2 \mathrm{ab}$ \\
Gramafante & $28.9 \mathrm{ab}$ & $15.0 \mathrm{~b}$ & $9.3 \mathrm{a}$ & $53.1 \mathrm{~b}$ \\
Bag 02 & $28.1 \mathrm{ab}$ & $17.8 \mathrm{ab}$ & $9.7 \mathrm{a}$ & $55.6 \mathrm{~b}$ \\
Roxo & $21.1 \mathrm{~b}$ & $18.8 \mathrm{ab}$ & $5.1 \mathrm{~b}$ & $45.0 \mathrm{c}$ \\
Cameroon & $32.0 \mathrm{a}$ & $20.1 \mathrm{a}$ & $10.9 \mathrm{a}$ & $63.1 \mathrm{a}$ \\
\hline Means & 27.7 & 18.9 & 8.4 & 55.0 \\
\hline
\end{tabular}

${ }^{(1)}$ Means followed by the same letters, in the columns, do not differ by Tukey's test at $5 \%$ probability. 
third cut, there was no statistical significance between genotypes in either soil. Considering the three cuts, on average, 296 and $292 \mathrm{~kg} \mathrm{ha}^{-1} \mathrm{~N}$ were accumulated by the plants in 22 months, when grown in the Acrisol and Planosol, respectively. Cameroon, Bag 02 and CNPGL F06-3 accumulated more $\mathrm{N}$ after the three cuts, in both Acrisol and Planosol. Quesada (2005) worked with various genotypes of elephant grass, including those used in the present study, obtained similar results and recorded $\mathrm{N}$ accumulations of $270 \mathrm{~kg} \mathrm{ha}^{-1} \mathrm{~N}$, in 15 months, without $\mathrm{N}$ fertilization.

These results are very promising, especially the high dry matter yield produced without the application of $\mathrm{N}$ fertilizer, which can represent more than $20 \%$ of all energy expenditure in biomass production of elephant grass, for direct burning purposes (Samson et al., 2005).

Table 3. Nitrogen accumulation of elephant grass genotypes, grown in two soils and subjected to three cuts, over a 22-month period ${ }^{(1)}$.

\begin{tabular}{lcccc}
\hline Genotype & $1^{\text {st }}$ cut & $2^{\text {nd }}$ cut & $3^{\text {rd }}$ cut & Total \\
\hline \multirow{5}{*}{ Acrisol } \\
CNPGL F06-3 & $105 \mathrm{a}$ & $129 \mathrm{a}$ & $68 \mathrm{a}$ & $302 \mathrm{ab}$ \\
Gramafante & $69 \mathrm{a}$ & $82 \mathrm{~b}$ & $81 \mathrm{a}$ & $232 \mathrm{~b}$ \\
Bag02 & $98 \mathrm{a}$ & $141 \mathrm{a}$ & $96 \mathrm{a}$ & $335 \mathrm{a}$ \\
Roxo & $95 \mathrm{a}$ & $125 \mathrm{a}$ & $50 \mathrm{a}$ & $270 \mathrm{~b}$ \\
Cameroon & $106 \mathrm{a}$ & $134 \mathrm{a}$ & $102 \mathrm{a}$ & $343 \mathrm{a}$ \\
\hline Means & 95 & 122 & 79 & 296 \\
\hline \multicolumn{5}{c}{ Planosol } \\
CNPGL F06-3 & $116 \mathrm{ab}$ & $135 \mathrm{a}$ & $45 \mathrm{a}$ & $296 \mathrm{ab}$ \\
Gramafante & $92 \mathrm{~b}$ & $94 \mathrm{~b}$ & $55 \mathrm{a}$ & $241 \mathrm{~b}$ \\
Bag02 & $117 \mathrm{ab}$ & $121 \mathrm{a}$ & $77 \mathrm{a}$ & $316 \mathrm{a}$ \\
Roxo & $117 \mathrm{ab}$ & $84 \mathrm{~b}$ & $39 \mathrm{a}$ & $240 \mathrm{~b}$ \\
Cameroon & $162 \mathrm{a}$ & $139 \mathrm{a}$ & $41 \mathrm{a}$ & $342 \mathrm{a}$ \\
\hline Means & 121 & 115 & 51 & 287 \\
\hline
\end{tabular}

${ }^{(1)}$ Means followed by the same letters, in the columns, do not differ by Tukey's test at $5 \%$ probability.
The high $\mathrm{N}$ accumulation indicates that BNF must be a key process for elephant grass cropping systems. The ${ }^{15} \mathrm{~N}$ abundance $\left(\delta^{15} \mathrm{~N}\right)$ found in the elephant grass genotypes were lower than in non- $\mathrm{N}_{2}$ fixing weeds, in all cases (Table 4), which confirms that the supply of $\mathrm{N}$ from BNF was appreciable. No significant differences between the ${ }^{15} \mathrm{~N}$ natural abundance of the different weed reference species were recorded. Thus, an average of the $\delta^{15} \mathrm{~N}$ values from the three control species sampled was considered to estimate the BNF to the elephant grass genotypes. The averaged $\delta^{15} \mathrm{~N}$ values of the reference species for the Acrisol were 6.53, 6.99 and 7.43 deltas for the $1^{\text {st }}, 2^{\text {nd }}$ and $3^{\text {rd }}$ cuts, respectively. For the Planosol, the $\delta^{15} \mathrm{~N}$ values were 7.89, 7.85 and 6.25 for the three cuts, respectively.

For the three cuts, there were statistically significant differences in BNF contributions for the plants. On the Acrisol, at the first cut, Roxo genotype presented $21 \%$ of its total $\mathrm{N}$ derived from BNF, the lowest contribution when compared to the others (Table 5). On Planosol, the reliance on BNF by Roxo was 30\%, again the lowest observed values, but only statistically different from CNPGL F06-3, which was of 52\%. For the second cut, the results changed slightly on the Acrisol, where Roxo presented an increased BNF reliance (43\%), compared to Bag $02(29 \%)$, but not different from Cameroon (43\%). However, on Planosol, which is usually more $\mathrm{N}$ deficient due to its sandy texture, genotype Roxo figured again among the genotypes with the lowest BNF reliance (35\%), being significantly different from genotype Cameroon $(47 \%)$. In the last cut, this same trend was observed for the two soils, with the lowest BNF reliance registered for genotype Roxo and the highest for genotype Cameroon.

Table 4. Nitrogen-15 natural abundance (\%o) of elephant grass genotypes and four weed species (non- $\mathrm{N}_{2}$-fixing reference).

\begin{tabular}{|c|c|c|c|c|c|c|}
\hline \multirow{2}{*}{$\begin{array}{l}\text { Genotype and reference } \\
\text { plant species }\end{array}$} & \multicolumn{3}{|c|}{ Acrisol } & \multicolumn{3}{|c|}{ Planosol } \\
\hline & $1^{\text {st }} \mathrm{cut}$ & $2^{\text {nd }}$ cut & $3^{\text {rd }}$ cut & $1^{\text {st }}$ cut & $2^{\text {nd }} c u t$ & $3^{\text {rd }}$ cut \\
\hline CNPGL F06-3 & $4.45 b$ & $4.09 \mathrm{~b}$ & $4.91 b$ & $3.81 b$ & $4.51 b$ & $4.02 b$ \\
\hline Gramafante & $4.51 b$ & $4.19 b$ & $5.15 b$ & $4.83 b$ & $4.46 b$ & $3.78 b$ \\
\hline Bag 02 & $4.25 b$ & $4.93 b$ & $4.95 b$ & $5.06 \mathrm{~b}$ & $4.57 b$ & $3.82 b$ \\
\hline Roxo & $5.14 b$ & $3.98 b$ & $5.69 b$ & $5.52 b$ & $5.02 \mathrm{~b}$ & $4.87 \mathrm{~b}$ \\
\hline Cameroon & $4.55 b$ & $3.98 b$ & $4.61 b$ & $4.91 b$ & $4.08 \mathrm{~b}$ & $3.49 b$ \\
\hline Emilia sonchifolia & $6.55 a$ & $7.06 \mathrm{a}$ & - & 7.71a & $7.71 \mathrm{a}$ & $6.18 \mathrm{a}$ \\
\hline Tradescantia fluminensis & $6.71 \mathrm{a}$ & $7.12 \mathrm{a}$ & $6.88 \mathrm{a}$ & $7.96 \mathrm{a}$ & $7.96 \mathrm{a}$ & $6.51 \mathrm{a}$ \\
\hline Arnica montana & $6.32 \mathrm{a}$ & $6.80 \mathrm{a}$ & $8.18 \mathrm{a}$ & $7.89 \mathrm{a}$ & $7.89 \mathrm{a}$ & $6.06 \mathrm{a}$ \\
\hline Richardia brasiliensis & - & - & $7.23 \mathrm{a}$ & - & - & - \\
\hline
\end{tabular}

${ }^{(1)}$ Means followed by the same letters, in the columns, do not differ by Tukey's test at $5 \%$ probability. 
Considering the results of all the three cuts, genotype Roxo stood out as the one that was least benefited from BNF, and genotype Cameroon as the most. Bag 02 and CNPGL F06-3 genotypes were intermediate. The largest contributions of BNF were observed in the Acrisol. These results agree with Quesada (2005) and Samson et al. (2005), who found BNF contributions of 58, 70 and $68 \%$ for the genotypes Cameroon, Bag 02, and Gramafante, respectively. They concluded that BNF presented the lower potential in Roxo genotype. There are few field studies showing that BNF can contribute to the $\mathrm{N}$ nutrition of elephant grass. However, the presence of $\mathrm{N}_{2}$ fixing bacteria of the genus Herbaspirillum inside this grass, detected by Kirchhof et al. (2001), reinforces the possibility that BNF is an important process to the survival and productivity of this species. The importance of BNF to other grass species was already shown, with contributions of BNF of 30 to $40 \%$ registered for Brachiaria (Boddey \& Victoria, 1986) and ecotypes of Panicum maximum (Miranda \& Boddey, 1987), respectively. In sugarcane, Urquiaga et al. (1992) found BNF could contribute up to $70 \%$ of the plant $\mathrm{N}$ needs, but the expected contribution of this process for sugarcane growing in farmer fields are of the order of $30 \%$, ranging from 0 to $60 \%$ (Boddey et al., 2001). The importance of this natural process must be highlighted as each $100 \mathrm{~kg} \mathrm{ha}^{-1}$ of $\mathrm{N}$ fertilizer that is substituted by BNF means a mitigation of about $450 \mathrm{~kg} \mathrm{ha}^{-1} \mathrm{CO}_{2}$, considering the phases of processing, transportation and fertiliser application (Robertson \& Grace, 2004).
Significant interaction between elephant grass genotypes and soil types was also observed for the qualitative parameters $\mathrm{C}: \mathrm{N}$ and stem:leaf ratios, and fibre, cellulose, lignin and ash contents (Table 6). All genotypes studied showed a high C:N ratio (above 70), especially the genotype Gramafante, which presented a C:N ratio 37\% above average, which could be explained by its high stem:leaf ratio and low $\mathrm{N}$ tissue content. In both soils, the $\mathrm{C}: \mathrm{N}$ ratio of genotype Gramafante (118 to 121) was significantly higher than in the other genotypes, except for genotype CNPGL F06-3. The stem:leaf ratio was not statistically different among genotypes, when plants were grown on the Acrisol, and the observed values ranged from 2.5, for genotype Gramafante, to 1.6, for genotype Roxo. Again, in the Planosol, the genotype Roxo presented the lowest stem:leaf ratio, on average $45 \%$ lower than that of the other genotypes. According to Ferrari Júnior \& Lavezzo (2001) and Queiroz Filho (1998, 2000), the shorter the time between cuts, the greater is the proportion of leaves in the produced biomass. In the case of animal feeding forage, silage or grazing, the recommendation is the short-time cutting intervals ( 1 to 2 months), which also end up with a plant material with increased protein levels (Andrade et al., 2005; Fagundes et al., 2007). For energy purposes, however, the strategy should be the opposite, as fibrous and low protein plant materials promote the most efficient heat production.

Few studies have reported the biomass quality of elephant grass for energy purposes. Quesada (2005)

Table 5. Nitrogen-15 natural abundance and the estimates of the proportional contribution of the biological nitrogen fixation (BNF) to the nutrition of elephant grass genotypes grown in two soils and subjected to three cuts, over a 22-month period ${ }^{(1)}$.

\begin{tabular}{|c|c|c|c|c|c|c|}
\hline \multirow[t]{2}{*}{ Genotype } & \multicolumn{2}{|c|}{$1^{\text {st }}$ cut } & \multicolumn{2}{|c|}{$2^{\text {nd }}$ cut } & \multicolumn{2}{|c|}{$3^{\text {rd }}$ cut } \\
\hline & $\delta^{15} \mathrm{~N}$ & $\mathrm{BNF}(\%)$ & $\delta^{15} \mathrm{~N}$ & $\mathrm{BNF}(\%)$ & $\delta^{15} \mathrm{~N}$ & BNF (\%) \\
\hline & \multicolumn{6}{|c|}{ Acrisol } \\
\hline PGL F06-3 & $4.45 \mathrm{a}$ & $32 \mathrm{a}$ & $4.09 \mathrm{a}$ & $42 \mathrm{ab}$ & $4.91 \mathrm{a}$ & $34 \mathrm{ab}$ \\
\hline Gramafante & $4.51 \mathrm{a}$ & $31 \mathrm{a}$ & $4.19 \mathrm{a}$ & $40 \mathrm{ab}$ & $5.15 \mathrm{a}$ & $31 \mathrm{ab}$ \\
\hline Bag 02 & $4.25 \mathrm{a}$ & $35 \mathrm{a}$ & $4.93 a$ & $29 b$ & $4.95 \mathrm{a}$ & $33 \mathrm{ab}$ \\
\hline Roxo & $5.14 \mathrm{a}$ & $21 b$ & $3.98 \mathrm{a}$ & $43 a$ & $5.69 \mathrm{a}$ & $23 b$ \\
\hline Cameroon & $4.55 \mathrm{a}$ & $30 \mathrm{a}$ & $3.98 \mathrm{a}$ & $43 a$ & $4.61 \mathrm{a}$ & $38 \mathrm{a}$ \\
\hline \multirow[t]{2}{*}{ Means } & 4.58 & 29.8 & 4.23 & 39.4 & 5.06 & 31.8 \\
\hline & \multicolumn{6}{|c|}{ Planosol } \\
\hline PGL F06-3 & $3.81 \mathrm{a}$ & $52 \mathrm{a}$ & $4.51 \mathrm{a}$ & $42 \mathrm{ab}$ & $4.02 \mathrm{a}$ & $36 \mathrm{ab}$ \\
\hline Gramafante & $4.83 \mathrm{a}$ & $38 \mathrm{ab}$ & $4.46 \mathrm{a}$ & $42 \mathrm{ab}$ & $3.78 \mathrm{a}$ & $39 \mathrm{ab}$ \\
\hline Bag 02 & $5.06 \mathrm{a}$ & $36 a b$ & $4.57 \mathrm{a}$ & $41 \mathrm{ab}$ & $3.82 \mathrm{a}$ & $39 \mathrm{ab}$ \\
\hline Roxo & $5.52 \mathrm{a}$ & $30 b$ & $5.02 \mathrm{a}$ & $35 b$ & $4.87 \mathrm{a}$ & $22 b$ \\
\hline Cameroon & $4.91 \mathrm{a}$ & $37 \mathrm{ab}$ & $4.08 \mathrm{a}$ & $47 \mathrm{a}$ & $3.49 \mathrm{a}$ & $44 a$ \\
\hline Means & 4.83 & 38.6 & 4.53 & 41.4 & 4.00 & 36.0 \\
\hline
\end{tabular}

${ }^{(1)}$ Means followed by the same letters, in the columns, do not differ by Tukey's test at $5 \%$ probability. 
Table 6. Carbon:nitrogen (C:N) ratio, stem:leaf ratio, concentrations of acid detergent fibre (ADF), cellulose, lignin, and ash contents of elephant grass genotypes grown in two soils and subjected to three cuts, over a 22-month period ${ }^{(1)}$.

\begin{tabular}{|c|c|c|c|c|c|c|}
\hline Genotype & $\mathrm{C}: \mathrm{N}$ & Stem:leaf & $\operatorname{ADF}(\%)$ & Cellulose $(\%)$ & Lignin (\%) & Ash (\%) \\
\hline & \multicolumn{6}{|c|}{ Acrisol } \\
\hline CNPGL F 06-3 & $98 \mathrm{ab}$ & $2.0 \mathrm{a}$ & $43.6 \mathrm{a}$ & $28.4 \mathrm{a}$ & $12.0 \mathrm{ab}$ & $1.9 \mathrm{ab}$ \\
\hline Gramafante & $118 \mathrm{a}$ & $2.5 \mathrm{a}$ & $42.8 \mathrm{a}$ & $27.3 \mathrm{a}$ & $11.8 \mathrm{ab}$ & $2.4 \mathrm{ab}$ \\
\hline Bag 02 & $90 \mathrm{~b}$ & $1.9 \mathrm{a}$ & $51.4 \mathrm{a}$ & $33.9 \mathrm{a}$ & $13.5 \mathrm{a}$ & $2.2 \mathrm{~b}$ \\
\hline Roxo & $87 \mathrm{~b}$ & $1.6 \mathrm{a}$ & $37.7 \mathrm{a}$ & $22.9 \mathrm{a}$ & $12.6 \mathrm{ab}$ & $2.2 \mathrm{ab}$ \\
\hline Cameroon & $84 \mathrm{~b}$ & $1.8 \mathrm{a}$ & $42.8 \mathrm{a}$ & $28.7 \mathrm{a}$ & $9.7 b$ & $3.0 \mathrm{a}$ \\
\hline \multirow[t]{2}{*}{ Means } & 95 & 2.0 & 43.7 & 28.2 & 11.9 & 3.0 \\
\hline & \multicolumn{6}{|c|}{ Planosol } \\
\hline CNPGL F 06-3 & $107 \mathrm{~b}$ & $2.2 \mathrm{a}$ & $40.3 \mathrm{a}$ & $27.4 \mathrm{ab}$ & $12.5 \mathrm{a}$ & $3.0 \mathrm{ab}$ \\
\hline Gramafante & $121 \mathrm{a}$ & $2.8 \mathrm{a}$ & $41.9 \mathrm{a}$ & $28.0 \mathrm{ab}$ & $13.7 \mathrm{a}$ & $2.8 \mathrm{ab}$ \\
\hline Bag 02 & $82 \mathrm{c}$ & $2.3 \mathrm{a}$ & $41.0 \mathrm{a}$ & $29.6 \mathrm{a}$ & $12.6 \mathrm{a}$ & $2.5 \mathrm{~b}$ \\
\hline Roxo & $75 \mathrm{c}$ & $1.1 \mathrm{~b}$ & $41.4 \mathrm{a}$ & $26.1 \mathrm{ab}$ & $12.6 \mathrm{a}$ & $2.5 \mathrm{ab}$ \\
\hline Cameroon & $73 \mathrm{c}$ & $2.1 \mathrm{a}$ & $41.6 \mathrm{a}$ & $26.8 b$ & $13.3 \mathrm{a}$ & $3.3 \mathrm{a}$ \\
\hline Means & 93.3 & 2.0 & 42.4 & 27.9 & 12.4 & 2.6 \\
\hline
\end{tabular}

(1) Means followed by the same letters, in the columns, do not differ by Tukey's test at $5 \%$ probability.

found $\mathrm{C}: \mathrm{N}$ ratio of about 95, when genotypes were grown on a Planosol, in the rainy season, and 55, when grown during the dry season.

The contents of acid detergent fibre (ADF) were not influenced by soil type, and all genotypes showed levels above $40 \%$ (Table 6). In studies with elephant grass grown for fodder purposes, the fibre content of the whole plant increases and protein content decreases, the longer the plant remains in the field (Andrade et al., 2005). The levels of fibre in the present study were similar to those reported by Savioli et al. (2000) and Campos et al. (2002), which recorded values close to $42 \%$, and by Queiroz Filho et al. (2000), which reported values up to $48 \%$, for plants growing for 100 days in the field. When grown on the Acrisol, all genotypes showed similar lignin content, except for genotype Cameroon, which was significantly lower $(9.7 \%)$ in this parameter than the genotype Bag 02 (13.5\%). When grown on the Planosol, no statistical difference was detected. According to McKendry et al. (2002), the levels of lignin and fibre observed in the genotypes used in the present study are considered satisfactory for energy production by direct combustion.

There was no statistically difference for cellulose contents in genotypes grown on the Acrisol, with values ranging from $22.9 \%$ (genotype Roxo) to $33 \%$ (genotype Bag 02). A small difference was detected on plants grown on the Planosol, with genotype Cameroon presenting the highest content $(26.2 \%)$ and genotype BAG $02(29.6 \%)$ the lowest. The contents of ash were more variable among genotypes, ranging from 1.9 to $3 \%$ when grown on Acrisol, the lowest value observed in the genotype CNPGL F06-3 and the largest in genotype Cameroon. On Planosol, ash contents varied from $2 \%$, for genotype Roxo, to $3.3 \%$, measured in genotype Cameroon.

Although significant differences were observed among treatments, the levels of fibre, lignin, cellulose and ash were still adequate for heat production, since the maximum ash level considered critical for the calorific value of the biomass is 5\% (McKendry, 2002; Kauter et al., 2003), high above the results found in the present work.

The results obtained so far, along with the work of Quesada (2001, 2005), indicate that this species has good adaptability to soils with low fertility, which is partially sustained by the significant contribution of BNF observed. Even though the BNF process could result in an apparent elephant grass independence of $\mathrm{N}$ fertilizer, more than $50 \%$ of the $\mathrm{N}$ required by the plant growth came from the soil. Thereby, the high $\mathrm{CO}_{2}$ mitigation potential of elephant grass production systems, shown in the present study, is only sustainable, in the long term, if some other nitrogen source is introduced.

\section{Conclusions}

1. The genotypes Cameroon, CNPGL F 06-3 and Bag 02 are the most promising for bioenergy production purposes.

2. The genotypes present lignin, cellulose and ash contents suitable for use in direct burning.

3. The reliance in biological nitrogen fixation of Pennisetum purpureum varies with soil and genotypes, and can reach up to $50 \%$ of this species $\mathrm{N}$ needs. 


\section{Acknowledgements}

To Fundação de Amparo à Pesquisa do Estado do Rio de Janeiro for financial and infrastructure support; to Coordenação de Aperfeiçoamento de Pessoal de Nível Superior and to Conselho Nacional de Desenvolvimento Científico e Tecnológico for fellowships and grants, respectively.

\section{References}

ANDRADE, A.C.; FONSECA, D.M. da; LOPES, R. dos S.; NASCIMENTO JÚNIOR, D. do; CECON, P.R.; QUEIROZ, D.S.; PEREIRA, D.H.; REIS, S.T. Análise de crescimento do capimelefante 'napier' adubado e irrigado. Revista Ciência Agrotécnica, v.29, p.415-423, 2005.

BALDANI，J.I.; OLIVARES， F.L.; HEMERLY，A.S.; REIS JÚNIOR, F.B.; OLIVEIRA, A.L.M.; BALDANI, V.L.D.; GOI, S.R.; REIS, V.M.; DOBEREINER, J. Nitrogen-fixing endophytes: recent advances in the association with graminaceous plants grown in the tropics. In: ELMERICH, C.; KONDOROSI, A.; NEWTON, W.E. (Ed.). Biological nitrogen fixation for the $21^{\text {st }}$ century. Netherlands: Kluwer Academic Publishers, 1998. p.203-206.

BODDEY, R.M.; POLIDORO, J.C.; RESENDE, A.S.; ALVES, B.J.R.; URQUIAGA, S. Use of the ${ }^{15} \mathrm{~N}$ natural abundance technique for the quantification of the contribution of $\mathrm{N}_{2}$ fixation to sugarcane and other grasses. Australian Journal of Plant Physiology, v.28, p.889-895, 2001.

BODDEY, R.M.; SOARES, L.H.B.; ALVES, B.J.R.; URQUIAGA, S. Bio-ethanol production in Brazil. In: PIMENTEL, D. (Ed.). Biofuels, solar and wind as renewable energy systems: benefits and risks. Berkeley: Springer, 2008. p.321-355.

BODDEY, R.M.; VICTORIA, R.L. Estimation of biological nitrogen fixation associated with Brachiaria e Paspalum notatum cv. batatais using ${ }^{15} \mathrm{~N}$ labelled organic matter and fertilizer. Plant Soil, v.90, p.265-292, 1986.

BOTREL, M.de A.; PEREIRA, A.V.; FREITAS, V. de P.; XAVIER, D.F. Potencial forrageiro de novos clones de capim-elefante. Revista Brasileira de Zootecnia, v.29, p.334-340, 2000.

CAMPOS, F.B. de; LANNA, D.P.D.; BOSE, M.L.V.; BOIN, C.; SARMENTO, P. Degradabilidade do capim-elefante em diferentes estágios de maturidade avaliada pelo método in vitro/gás. Scientia Agricola, v.59, p.217-225, 2002.

FAGUNDES, J.L.; FONSECA, D.M.; MISTURA, C.; SALGADO, L.T.; QUEIROZ, D.S.; MORAIS, R.V.; VITOR, C.M.T.; MOREIRA, L.M. Adubação nitrogenada e potássica em capimelefante cv. Napier sob pastejo rotativo. Boletim de Indústria Animal, v.64, p.149-158, 2007.

FERRARI JÚNIOR, E.; LAVEZZO, W. Qualidade da silagem de capim-elefante (Pennisetum purpureum Schum.) emurchecido ou acrescido de farelo de mandioca. Revista Brasileira de Zootecnia, v.30, p.1424-1431, 2001.

KAUTER, D.; LEWANDOWSKI, I.; CLAUPEIN, W. Quantity and quality of harvestable biomass from Populus short rotation coppice for solid fuel use - a review of the physiological basis and management influences. Biomass and Bioenergy, v.24, p.411-427, 2003.

KIRCHHOF, G.; ECKERT, B.; STOFFELS, M.; BALDANI, J.I.; REIS, V.M.; HARTMANN, A. Herbaspirillum frisingense sp. nov., a new nitrogen-fixing bacterial species that occurs in $\mathrm{C}_{4}$-fibre plants. International Journal of Systematic and Evolutionary Microbiology, v.51, p.157-168, 2001.

KRAXNER, F.; NILSSON, S.; OBERSTEINER, M. Negative emissions from bioenergy use, carbon capture and sequestration (BECS) - the case of biomass production by sustainable forest management from semi-natural temperate forests. Biomass and Bioenergy, v.24, p.285-296, 2003.

LEMUS, R.; BRUMMER, E.C.; MOORE, K.J.; MOLSTAD, N.E.; BURRAS, C.L.; BARKER, M.F. Biomass yield and quality of 20 switchgrass populations in southern Iowa, USA. Biomass and Bioenergy, v.23, p.433-442, 2002.

MAGALHÃES, J.A.; LOPES, E.A.; RODRIGUES, B.H.N.; COSTA, N.de L.; BARROS, N.N.; MATTEI, D.A. Influência da adubação nitrogenada e da idade de corte sobre o rendimento forrageiro do capim-elefante. Revista Ciência Agronômica, v.37, p.91-96, 2006.

MCKENDRY, P. Energy production from biomass (part 1): overview of biomass. Bioresource Technology, v.83, p.37-46, 2002.

MIRANDA, C.H.B.; BODDEY, R.M. Estimation of biological nitrogen fixation associated with 11 ecotypes of Panicum maximum grown in nitrogen-15 labeled soil. Agronomy Journal, v.79, p.558-563, 1987.

MOREIRA, L.de M.; FONSECA, D.M. da; MARTUSCELLO, J.A.; NÓBREGA, E.B. da. Absorção e níveis críticos de fósforo na parte aérea para manutenção da produtividade de capim-elefante (Pennisetum purpureum cv. Napier). Ciência Agrotécnica, v.30, p.1170-1176, 2006.

QUEIROZ FILHO, J.L. de; SILVA, D.S. da; NASCIMENTO, I.S. do. Dry matter production and quality of elephant grass (Pennisetum purpureum Schum.) cultivar Roxo at different cutting ages. Revista Brasileira de Zootecnia, v.29, p.69-74, 2000 .

QUEIROZ FILHO, J.L. de; SILVA, D.S. da; NASCIMENTO, I.S. do. Produção de matéria seca de cultivares e qualidade de cultivares de capim-elefante (Pennisetum purpureum Schum.). Revista Brasileira de Zootecnia, v.27, p.262-266, 1998.

QUESADA, D.M. Parâmetros quantitativos e qualitativos da biomassa de genótipos de capim-elefante (Pennisetum purpureum Schum.) com potencial para uso energético, na forma de carvão vegetal. 2005. 86p. Tese (Doutorado) - Universidade Federal Rural do Rio de Janeiro, Seropédica.

QUESADA, D.M. Seleção de genótipos de capim-elefante (Pennisetum purpureum Schum.) para a alta produção de biomassa e eficiência da fixação biológica de nitrogênio (FBN). 2001. 86p. Dissertação (Mestrado) - Universidade Federal Rural do Rio de Janeiro, Seropédica.

ROBERTSON, G.P.; GRACE, P.R. Greenhouse gas fluxes in tropical and temperate agriculture: the need for a full-cost accounting of 
global warming potentials. Environment, Development and Sustainability, v.6, p.51-63, 2004.

SAMSON, R.; MANI, S.; BODDEY, R.; SOKHANSANJ, S.; QUESADA, D.; URQUIAGA, S; REIS, V.; HO LEM, C. The potential of $\mathrm{C}_{4}$ perennial grasses for developing a global BIOHEAT industry. Critical Reviews in Plant Sciences, v.24, p.461-495, 2005.

SANTOS, H.G. dos; JACOMINE, P.K.T.; ANJOS, L.H.C. dos; OLIVEIRA, V.A. de; OLIVEIRA, J.B. de; COELHO, M.R.; LUMBRERAS, J.F.; CUNHA, T.J.F. (Ed.). Sistema brasileiro de classificação de solos. 2.ed. Rio de Janeiro: Embrapa Solos, 2006. $306 \mathrm{p}$.

SAVIOLI, N.M. de F.; FUKUSHIMA, R.S.; LIMA, C.G.; GOMIDE, C.A. Rendimento e comportamento espectrofotométrico da lignina extraída de preparações de parede celular, fibra em detergente neutro ou fibra em detergente ácido. Revista Brasileira de Zootecnia, v.29, p.988-996, 2000.

SMITH, J.L.; MYUNG, H.U. Rapid procedures for preparing soil and $\mathrm{KCl}$ extracts for ${ }^{15} \mathrm{~N}$ analysis. Communication in Soil Science and Plant Analysis, v.21, p.2173-2180, 1990.
UNIVERSIDADE FEDERALDE VIÇOSA. Sistema para análises estatísticas. Versão 9.1. Viçosa: Fundação Arthur Bernardes, 2007. 1 CD-ROM.

UNKOVICH, M.J.; HERRIDGE, D.F.; PEOPLES, M.B.; CADISCH, G.; BODDEY, R.M.; GILLER, K.E.; ALVES, B.; CHALK, P. Measuring plant-associated nitrogen fixation in agricultural systems. Canberra: ACIAR, 2008. 258p.

URQUIAGA, S.; CRUZ, K.H.S.; BODDEY R.M. Contribution of nitrogen fixation to sugarcane $\mathrm{N}-15$ and nitrogen balance estimates. Soil Science Society of America Journal, v.56, p.105-114, 1992.

VAN SOEST, P.J.; WINE, R.H. The determination of lignin and cellulose in acid-detergent fibre with permanganate. Journal of the Association of Official Analytical Chemists, v.51, p.780-785, 1968.

YONEYAMA, T.; MURAOKA, T.; KIM, T.H.; DACANAY, E.V.; NAKANISHI, Y. The natural ${ }^{15} \mathrm{~N}$ abundance of sugarcane and neighbouring plants in Brazil, the Philippines and Miyako (Japan). Plant and Soil, v.189, p.239-244, 1997. 